\title{
WATERFOWL AS INDICATORS OF THE STATE OF WETLAND ECOSYSTEMS
}

\author{
Mycola Prychepa ${ }^{1}$ \\ Yuliia Kovalenko ${ }^{2}$
}

DOI: https://doi.org/10.30525/978-9934-26-050-6-4

It is known that any impact from human activities can change the habitat of living organisms (aquatic and terrestrial), disrupting their life processes. Due to the intensification of urbanization processes, all new inland water bodies are under the threat of transformation, which leads to a decrease in water quality and a decrease in biological diversity (in particular, species that are protected by the Bern and Bonn conventions, as well as those listed in Red Book of Ukraine), which exists in little-transformed territories. In this regard, an assessment of the ecological state is essential. For this, not only chemical control methods are used, but also bioindication methods. The state of the city's avifauna, in particular, wetlands (its qualitative and quantitative composition) may reflect the general ecological state of a certain territory.

Birds as an integral part of ecosystems associated with its components by topical and trophic connections, in particular, these are higher aquatic plants (density of overgrowth and species composition), aquatic and near-aquatic animals [1, p. 2398]. Taking this into account, methods for indicating freshwater ecosystems using birds have been used in the world for a long time [3, p. 9].

It gave grounds to transfer the results of avifauna studies to groups of other species of vertebrates, including amphibians, fish and mammals [4, p. 675]. Also, birds play an important role in the spread of various parasites [5, p. 57], which has a direct impact on the components of the ecosystem.

The use of birds as biomarkers of the state of the environment allows you to take samples in vivo, which is consistent with the principles of bioethics [6, p. 124]. To study the effects of chronic pollution on the aquatic environment, the most suitable objects are those at the top of the food pyramid predatory and piscivorous species. It is known that bird feathers - accumulate toxic compounds [7, p. 356]. Analyzing the feathers of birds can determine the content of heavy metals in the body of the bird. Comparing feathers from different groups, it is possible to compare the level of pollution in different areas.

\footnotetext{
${ }^{1}$ Institute of Hydrobiology of the National Academy of Sciences of Ukraine, Ukraine

${ }^{2}$ Institute of Hydrobiology of the National Academy of Sciences of Ukraine, Ukraine
} 
As well, the number of birds correlates with the hydrological conditions of water bodies, since birds are indicative in the study of changes in the hydromorphology of river beds and fragmentation of its valley [8, p. 2270]. The importance of certain groups of birds, including those confined to certain biotopes (specialized species) in wetland ecosystems, make it possible to understand the role of birds as ecological indicators in general. An assessment of the ecological state of aquatic ecosystems, coastal landscapes and biotopic diversity can be carried out by quantitative assessment of coastal birds, which are sensitive to changes in the moisture content of areas adjacent to the river, a decrease in the water level, changes in the flow regime, etc [9, p. 261; 1, p. 2383]. A decrease in the number of specialized species with an increase in the number of universal species can be interpreted as a transition of an ecosystem from a stable to a degraded one. An example of such a transition is the change in the number of nesting groups of waterbirds in water bodies and wet meadows as a result of the transformation of their habitat, which is shown in Figure 1 and Figure 2.

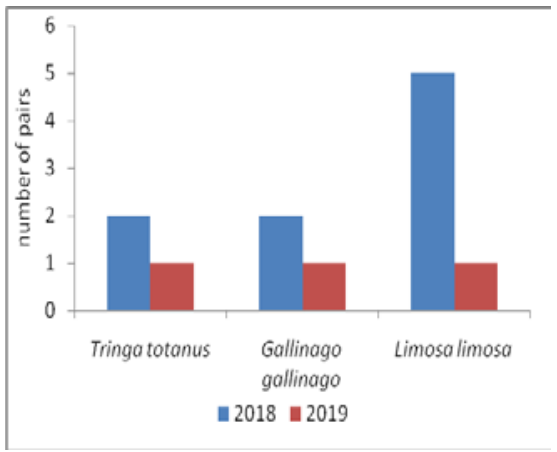

Figure 1. Changes in the number of nesting pairs of waders as a result of landscape transformation in floodplain meadows in the river valley. Desna (near Kiev, Ukraine)

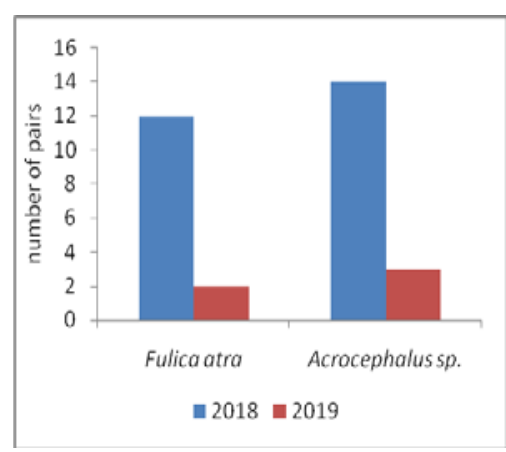

Figure 2. Changes in the number of breeding pairs as a result of the domestication of Lake Jordanske (Kiev, Ukraine)

It is these examples that clearly illustrate the change in nesting groups (even relatively tolerant species - Fulica atra) and make it possible to assess the ecological state of wetlands, including park water bodies and wet meadow (habitats of specialized species - Tringa totanus, Limosa limosa) along river valleys in conditions of transformation or fragmentation of biotopes.

When studying the number, distribution of piscivorous birds, the peculiarities of their biology and helminth fauna, it is possible to establish the 
role of ichthyophagous birds in the spread of fish parasites, as well as to identify test objects that can be used to determine the pathways of the formation of natural sources of helminthic zoonoses in the reservoir [5, p. 57]. This question is also interesting from the point of view of comparing degraded and poorly transformed water bodies close to the natural state, in particular, floodplain lakes and oxbow lakes. So, in particular, seagulls and herons that nest on water bodies produce a large amount of organic matter, as a rule, affect its ecological and sanitary state. This has a significant effect on the accumulation of biogenic compounds and the processes of eutrophication of the reservoir [10, p. 63; 11 p. 121].

This question is also interesting from the point of view of comparing degraded and poorly transformed water bodies close to the natural state, in particular, floodplain lakes and oxbow lakes. So, in particular, seagulls and herons that nest on water bodies produce a large amount of organic matter, as a rule, affect its ecological and sanitary state. This has a significant effect on the accumulation of biogenic compounds and the processes of eutrophication of the reservoir [10, p. 63; 11 p. 121].

Bioindication of the general state of the environment by monitoring the species, qualitative composition and residence status of waterfowl and semiaquatic birds, provides express information about sudden changes in ecosystems without interfering with it. Based on this assessment, it is possible to determine in advance the improvement or deterioration of the ecological state of the environment and make appropriate environmental decisions.

\section{References:}

1. Mistry, J, Berardi, A, Simpson, M. (2008). Birds as indicators of wetland status and change in the North Rupununi, Guyana. Biodiversity and Conservation, vol. 17, no. 10, pp. 2383-2409. doi: 10.1007/s10531-008-9388-2

2. Gregory, R. D., van Strien, A., Vorisek, P., Meyling, A.W.G., Noble, D.G., Ruud, P. B., Foppen, R. P. B.,Gibbons, D. W. (2005). Developing indicators for European birds. Phil. Trans. R. Soc. B., vol. 360, pp. 269-288. doi: 10.1098/rstb.2004.1602

3. Noble, D., Everard, M., Andrew Joys, A. (2008). Development of wild bird indicators for freshwater wetlands and waterways: provisional indicators // British Trust for Ornithology, The Nunnery, Thetford, Norfolk IP24 2PU Registered Charity, no. 216652, p. 41.

4. Kati, V., Devillers, P., Dufrene, M., Legakis, A., Vokon, D., Lebrun, P. (2004). Testing the value of six taxonomic groups as biodiversity indicators at a local scale. Conservation biology, vol. 18, no. 3, pp. 667-675.

5. Shabunov, A. A., Radchenko, N. M. (2002). Chaykovyye ptitsy kak bioindikatory sostoyaniya ekosistem. [Gull birds as bioindicators of the state 
of ecosystems]. Information-methodical and scientific-pedagogical journal «Source». Vologda, Ed. Center VIRO, no. 1, pp. 55-58.

6. Medvedev, N. V. (2001). Khimicheskoye zagryazneniye ptits i mlekopitayushchikh. Gosudarstvennyy doklad o sostoyanii okruzhayushchey prirodnoy sredy Respubliki Kareliya v 2000 godu [Chemical pollution of birds and mammals. State report on the state of the environment in the Republic of Karelia in 2000]. Petrozavodsk, pp. 122-124.

7. Pilastro, A., Congin, L., Tallandini, L., Turchetto, M. (1993).The use of bird feathers for the monitoring of cadmium pollution. Archives of Environmental Contamination and Toxicology, vol. 24, no. 3, pp. 355-358.

8. Vaughan, I. P, Noble, D. G, Ormerod, S. J. (2007). Combining surveys of river habitats and river birds to appraise riverine hydromorphology. Freshw. Biol., vol. 52, no. 11, pp. 2270-2284. doi: 10.1111/j.13652427.2007.01837.x

9. Larsen, S., Sorace, A., Mancini, L. (2010). Riparian bird communities as indicators of human impacts along Mediterranean streams. Environ Manage., vol. 45, no. 2, pp. 261-273. doi: 10.1007/s00267-009-9419-0

10. Siokhin, V. D. (1981). Troficheskiye svyazi chaykovykh ptits v nazemnykh i vodnykh ekosistemakh Prisivash'ya. Ekologo-morfologicheskiye osobennosti zhivotnykh i sreda ikh obitaniya [Trophic relationships of gull birds in terrestrial and aquatic ecosystems of the Sivash region. Ecological and morphological characteristics of animals and their habitat]. Kyiv. (in Ukrainian)

11. Manny, B. A., Johnson, W. C., Wetzel R. G. (1994). Nutrient additions by waterfowl to lakes and reservoirs: predicting their effects on productivity and water quality. Hydrobiologia., vol. 279/280, no. 1, pp. 121-132. doi: 10.1007/BF00027847 